\title{
ADSORPSI MULTI LOGAM BERAT KROM(III), TIMBAL(II), DAN TEMBAGA(II) DALAM SISTEM LARUTAN BINARY OLEH SILIKA GEL TERIMOBILISASI DIFENILKARBAZIDA
}

\author{
I W. Sudiarta ${ }^{1^{*}}$, P. Suarya ${ }^{1}$, dan C. M. P. Widya ${ }^{1}$ \\ ${ }^{1}$ Program Studi Kimia Fakultas Matematika dan Ilmu Pengetahuan Alam Universitas Udayan, Bukit \\ Jimbaran, Badung, Bali 80364 \\ *E-mail: wayansudiarta@unud.ac.id
}

\begin{abstract}
ABSTRAK
Adsorpsi multi ion logam, timba $1(\mathrm{~Pb})$, tembaga $(\mathrm{Cu})$, dan krom $(\mathrm{Cr})$ dalam sistem larutan binary $\mathrm{Pb}(\mathrm{II})$ $\mathrm{Cr}(\mathrm{III}), \mathrm{Cr}(\mathrm{III})-\mathrm{Cu}(\mathrm{II})$, dan $\mathrm{Pb}(\mathrm{II})-\mathrm{Cu}(\mathrm{II})$ menggunakan adsorben silika gel terimobilisasi difenilkarbazida (SiDPZIDA) dengan metode bath adsorpsi pada $\mathrm{pH} 2$ dan waktu pengadukan 8 jam. Sistem larutan binary terdiri dari ion logam utama dan ko-kation, dengan konsentrasi logam ko-kation bervariasi 0,5; 1,0; dan 1,5 mM, sedangkan konsentrasi ion logam utama tetap 5,0 mM. Tujuan adsorpsi multi ion logam ini adalah untuk mengetahui efek dari kehadiran ko-kation terhadap adsorpsi ion logam utama. Hasil penelitian menunjukkan bahwa kehadiran Cr(III) maupun $\mathrm{Cu}$ (II) sebagai ko-kation memberikan efek sinergis terhadap daya serap $\mathrm{Pb}(\mathrm{II})$, sinergistik tertinggi terjadi pada konsentrasi $\mathrm{Cr}(\mathrm{III})$ 1,5 M dan $\mathrm{Cu}$ (II) 1,0 mM dengan daya serap $\mathrm{Pb}$ (II) masing-masing 0,5808 dan 0,5867 $\mathrm{mmol} / \mathrm{g}$. Daya adsorpsi logam $\mathrm{Cr}$ (III) mengalami efek sinergistik dengan kehadiran ko-kation $\mathrm{Pb}$ (II) maupun $\mathrm{Cu}(\mathrm{II})$. Efek sinergis terbesar terjadi pada konsentrasi $\mathrm{Pb}$ (II) $0,5 \mathrm{mM}$ dan $\mathrm{Cu}$ (II) $0,5 \mathrm{mM}$, masing-masing dengan daya sorpsi $\mathrm{Cr}$ (III) 0,1041 dan 0,1010 mmol/g. Pada adsorpsi ion logam utama $\mathrm{Cu}$ (II), kehdiaran $\mathrm{Cr}$ (III) maupun $\mathrm{Pb}$ (II) memberikan efek antagonistik. Efek antagonistik tertinggi terjadi pada kehadiran ko-kation $\mathrm{Cr}$ (III) dan $\mathrm{Pb}(\mathrm{II}) \mathrm{pada}$ konsentrasi 0,5 mM dan 0,5 mM, dengan daya serap $\mathrm{Cu}(\mathrm{II})$ masing-masing sebesar 0,2768 dan 0,2736 mmol/g.
\end{abstract}

Kata kunci: adsoprsi multi logam, larutan binary, silika gel terimobilisasi, efek sinergistik, dan antagonistik

\begin{abstract}
The adsorption of multi-metal ions of lead $(\mathrm{Pb})$, copper $(\mathrm{Cu})$, and chromium $(\mathrm{Cr})$ was carried out in a binary solution systems of $\mathrm{Pb}(\mathrm{II})-\mathrm{Cr}(\mathrm{III}), \mathrm{Cr}(\mathrm{III})-\mathrm{Cu}(\mathrm{II})$, and $\mathrm{Pb}(\mathrm{II})-\mathrm{Cu}$ (II) using a diphenylcarbazide immobilized silica gel adsorbent (Si-DPZIDA) by bath adsorption method at $\mathrm{pH} 2$ and 8 hours stirring time. The binary solution system consists of major metal ions and co-cations, wherein the co-cation metal concentration were varies from 0.5 , 1.0 , and $1.5 \mathrm{mM}$, while concentration of major metal ions remained $5.0 \mathrm{mM}$. The purpose of this multi ion metal adsorption is to know the effect of the presence of co-cation on the adsorption of major metal ions. The results showed that the presence of $\mathrm{Cr}$ (III) and $\mathrm{Cu}$ (II) as co-cation gave a synergistic effect on the absorption capacity of $\mathrm{Pb}$ (II). The highest synergistic occurred at $\mathrm{Cr}$ (III) concentration of $1.5 \mathrm{M}$ and that of $\mathrm{Cu}$ (II) of $1.0 \mathrm{mM}$ with absorption capacity of $\mathrm{Pb}$ (II) each 0.5808 and $0.5867 \mathrm{mmol} / \mathrm{g}$. The adsorption power of $\mathrm{Cr}$ (III) metal experiences a synergistic effect in the presence of co-cations $\mathrm{Pb}$ (II) and $\mathrm{Cu}$ (II). The largest synergistic effect occurred at the $\mathrm{Pb}$ (II) concentrations of 0.5 $\mathrm{mM}$ and $\mathrm{Cu}$ (II) $0.5 \mathrm{mM}$, respectively with $\mathrm{Cr}$ (III) sorption 0.1041 and $0.1010 \mathrm{mmol} / \mathrm{g}$. In the adsorption of major $\mathrm{Cu}$ (II) metal ions, the presence of $\mathrm{Cr}$ (III) and $\mathrm{Pb}$ (II) gives antagonistic effects. The highest antagonistic effect occurred in the presence of $\mathrm{Cr}$ (III) and $\mathrm{Pb}$ (II) co-cations at $0.5 \mathrm{mM}$ and $0.5 \mathrm{mM}$ concentrations, with $\mathrm{Cu}(\mathrm{II})$ absorption of 0.2768 and $0.2736 \mathrm{mmol} / \mathrm{g}$.
\end{abstract}

Keywords: multi-metal adsorption, immobilized silica gel, synergistic, antagonistic effects

\section{PENDAHULUAN}

Timbal $(\mathrm{Pb})$, tembaga $(\mathrm{Cu})$, nikel $(\mathrm{Ni})$, krom $(\mathrm{Cr})$, merkuri $(\mathrm{Hg})$, dan arsen (As) merupakan logam-logam yang banyak digunakan dalam perindustrian seperti industri pelapisan logam, industri cat dan zat warna tekstil, serta industri penyamakan kulit. Industri-industri tersebut dapat menghasilkan limbah yang mengandung logamlogam yang ikut terbawa dalam limbah industri 
dan bersifat stabil. Keberadaan logam dalam tubuh dapat masuk melalui rantai makanan (oral), melalui pernafasan (inhalasi), dan melalui kulit (absorpsi). Beberapa logam berat seperti timbal, nikel, kadminium, arsen, krom sering dijumpai dalam air buangan yang bersifat karsinogenik dan toksik terhadap lingkungan (Kocasoy, \& Sahin, 2007).

Keberadaan multi logam dalam air limbah menyebabkan dampak interaktif tergantung pada beberapa faktor seperti jumlah ko-kation yang berkompetisi pada situs-situs aktif, konsentrasi ion logam, $\mathrm{pH}$, sifat dan jumlah adsorben (Saeed, et al., 2005).

Treatmen terhadap air limbah merupakan peluang besar dalam rekayasa lingkungan dan pembuatan kebijakan. Beberapa teknologi yang cocok untuk treatmen air limbah yang mengandung ion-ion logam berat antara lain presipitasi kimia, osmosis balik, redoks, elektrodialisis, dan adsorpsi. Adsorpsi merupakan teknologi yang banyak dikembangkan dan cocok untuk beragam air yang mengandung logam berat dalam jumlah kelumit (trace) dan yang tidak dapat dihilangkan dengan metode lain. Adsorpsi dapat diterapkan untuk treatmen air limbah menggunakan beragam material sebagai adsorben, seperti limbah pertanian, alga, bakteri, fungi, zeolit, lempung, karbon aktif, dan silika (Oscik, 1982).

Penelitian tentang adsorpsi ion logam berat yang dilaporkan dalam literatur sebagian besar berupa adsorpsi dari larutan mono-ion logam (Vinh, et al., 2015; Reddy, et al., 2015; Ghasemi, et al., 2014; Mahajan \& Sud, 2013; Machida et al., 2006). Adsorpsi multi logam penting dipelajari untuk mengetahui tingkat interferensi dari kehadiran ko-kation dalam air limbah dan efisiensi adsorben dalam menghilangkan ion-ion tersbut dari air limbah (Srivastva, et al., 2006). Adsorpsi kompetitif berbagai ion logam berat dalam sistem multi-logam telah dilaporkan belakangan ini oleh beberapa peneliti. Hadi, et al., (2014) melaporkan adsorpsi $\mathrm{Cu}, \mathrm{Pb}$, dan $\mathrm{Zn}$ dari single, binary dan ternary system menggunakan adsorben berbahan limbah pertanian. Mohan \& Singh (2002) menemukan bahwa kapasitas adsorpsi karbon aktif untuk Cd(II)dan Zn(II) menurun dalam system multi-logam dibandingkan dengan dalam sistem binary. Chiban, et al. (2011) melaporkan bahwa kapasitas adsorpsi $\mathrm{Pb}$ (II) dalam Carpobrothus edulis kering, menurun dengan kehadiran $\mathrm{Cd}(\mathrm{II})$ dalam sistem binary. Ting \& Teo (1994), melaporkan bahwa dalam system multi-komponen, ion-ion logam berinteraksi satu dengan lainnya dengan jenis interaksi sinergis, antagonis, dan noninteraktif. Sifat interaksi ko-kation dengan logam utama tidak dapat diprediksi berdasarkan studi logam tunggal, karena itu adsorpsi simultan dua logam atau lebih penting untuk dipelajari.

Penghilangan logam-logam toksik melalui adsorpsi menggunakan karbon aktif dari berbagai biomassa, kitosan dan agar telah dilaporkan oleh beberapa peneliti. Selektivitas adsorpsi ion-ion logam berbeda pada setiap adsorben (Myroslav, et al., 2006). Tingkat kompetitif ion-ion logam dalam berinteraksi dengan adsorben bervariasi sesuai dengan adsorben yang digunakan. Selektivitas adsorpsi kaolinit dalam sistem multi ion logam berat adalah $\mathrm{Pb}<\mathrm{Cu}<\mathrm{Zn}<\mathrm{Cd}$ (Srivastava, et al., 2005). Selektivitas adsorpsi zeolit alam adalah $\mathrm{Co}^{2+} \mathrm{Co}^{2+}>\mathrm{Cu}^{2+}>\mathrm{Zn}^{2+}>\mathrm{Mn}^{2+}$ (Erdem, et al., 2004).

Pemanfaatan silika gel termodifikasi sebagai adsorben telah banyak di teliti. Mahmoud \& AlSaadi (2007) melaporkan hasil penelitiannya mengenai sintesis silika gel termodifikasi difenilkarbazon (DPCZ) untuk ektraksi dan prekonsentrasi $\mathrm{Cr}$ (III) dan $\mathrm{Fe}$ (III) dimana hasil yang diperoleh dari adsorpsi terbaik oleh Si-DPCZ terhadap logam $\mathrm{Cr}(\mathrm{III})$ adalah $0,350 \mathrm{mmol} / \mathrm{g}$ serta aplikasinya yang potensial untuk Si-DPCZ bagi ekstraksi selektif dan pre-konsentrasi bagi ion logam berat $\mathrm{Cr}$ (III) dalam tingkat konsentrasi ppm dan ppb telah dengan sukses ditunjukkan dengan presentase penemuan kembali lebih dari 95\% untuk ion logam yang telah diujikan. Kemampuan adsorpsi silika gel tanpa modifikasi dan silika gel terimpregnasi difenilkarbazida dalam menurunkan $\mathrm{Cr}$ (III) secara berturut-turut sebesar 1,95\% dan $25,78 \%$. Hasil penelitiannya ini juga menunjukkan peningkatan kemampuan adsorpsi untuk $\mathrm{Cr}$ (III) dan $\mathrm{Cr}(\mathrm{IV})$ pada silika gel terimpregnasi difenilkarbazida bila dibandingkan dengan silika gel tanpa modifikasi (Mandala, 2012). Tujuan dari penelitian ini adalah untuk mengetahui pengaruh ko-kation terhadap kapasitas adsorpsi kation utama dalam sistem larutan binary $\mathrm{Pb}$ (II)- $\mathrm{Cu}$ (II), $\mathrm{Pb}$ (II)$\mathrm{Cr}$ (III), $\mathrm{Cu}$ (II)- $\mathrm{Pb}$ (II), $\mathrm{Cu}$ (II)-Cr(III), $\mathrm{Cr}$ (III)-Pb(II), dan $\mathrm{Cr}(\mathrm{III})-\mathrm{Cu}(\mathrm{II})$. 


\section{MATERI DAN METODE PENELITIAN}

\section{Bahan dan Peralatan Penelitian}

Bahan-bahan yang digunakan adalah $\mathrm{CrCl}_{3} .6 \mathrm{H}_{2} \mathrm{O}, \mathrm{CuSO}_{4}, \mathrm{~Pb}\left(\mathrm{NO}_{3}\right)_{2}, \mathrm{HNO}_{3}, \mathrm{HCl} 37 \%$, Silika Gel Terimmobilisasi difenilkarbazida (SiDPZIDA, $\mathrm{NaOH}, \mathrm{H}_{2} \mathrm{SO}_{4}, \mathrm{HNO}_{3}$, Toluena, ethyl alkohol, dietil eter, silika gel 60, larutan buffer $\mathrm{pH}$ $1-7$, akuades, dan akua demineralisasi.

Alat-alat yang diguanakan antara lain serangkat alat-alat gelas, Shaker, Magnetic strirer, Spektrofotometer Serapan Atom (AAS), pH meter dan kertas saring Whatman 42.

\section{Adsorpsi Mono Komponen}

Semua adsorpsi dikerjakan dengan sistem bath adsorption. Adsorpsi mono-komponen $\mathrm{Cr}$ (III), $\mathrm{Cu}(\mathrm{II})$, dan $\mathrm{Pb}(\mathrm{II})$ dikerjakan untuk mengetahui adsorpsi masing-masing logam pada sistem larutan mono-logam. $50 \mathrm{~mL}$ larutan ion logam $1 \times 10^{-3} \mathrm{M}$ dicampur dengan $0,2 \mathrm{~g}$ adsorben $(\mathrm{dosis}=0,2 \mathrm{~g} / 50$ $\mathrm{mL}$ ) diaduk pada kecepatan tetap selama 3 jam pada suhu kamar. Semua eksperimen dikerjakan pada $\mathrm{pH} 2$ ( $\mathrm{pH}$ optimum $\mathrm{Cr}(\mathrm{III})$ ) dan dilakukan tiga kali ulangan (Jain, et al., 2010; 2013;). Jumlah logam yang terserap, $\mathrm{q}_{\mathrm{e}}$, (mMol logam per $\mathrm{g}$ adsoreben ) untuk setiap sistem adsorpsi dihitung menggunakan persamaan (1):

$$
q e\left(\frac{m M o l}{g}\right)=\frac{(C i-C e)}{M} \times V
$$

dimana, $\mathrm{Ci}$ dan $\mathrm{Ce}$ adalah konsentrasi awal dan kesetimbangan logam, $\mathrm{V}$ adalah volume larutan dalam liter (L), M adalah massa adsorben dalam gram (g). Konsentrasi ion logam sisa dalam larutan ditentukan dengan spektrometer serapan atom (AAS)

\section{Adsorpsi multi-komponen sistem binary}

Pengaruh ko-kation dalam adsorpsi $\mathrm{Cr}$ (III), $\mathrm{Cu}(\mathrm{II})$, dan $\mathrm{Pb}(\mathrm{II})$ oleh silika gel terimpregnasi difenilkarbazida dipelajari dalam komponen sistem binary. Desain percobaan yang digunakan dalam sistem binary adalah $\mathrm{Pb}$ (II)-Cr(III), $\mathrm{Pb}$ (II)-Cu(II), $\mathrm{Cu}$ (II)-Cr(III), bergantian sebagai kation utama dan ko-kation. Pengaruh ko-kation terhadap kapasitas adsorpsi $\mathrm{Pb}(\mathrm{II}), \mathrm{Cu}(\mathrm{II})$, dan $\mathrm{Cr}(\mathrm{III})$ dipelajari pada berbagai konsentrasi ko-kation yaitu 0,$5 ; 1,0$; dan $1,5 \mathrm{mM}$ dengan dosis setiap sistem yaitu $0,1 \mathrm{~g} / 25 \mathrm{~mL}$. Adsorpsi dikerjakan sesuai dengan $\mathrm{pH}$ optimum kation utama. Jumlah logam yang tersisa dalam setiap adsorpsi ditentukan dengan AAS.

\section{HASIL DAN PEMBAHASAN}

Studi adsorpsi silika gel terimobilisasi difenilkarbazida (Si-DPZIDA) terhadap logamlogam berat dalam sistem larutan binary dilakukan dengan menginteraksikan $0,1 \mathrm{~g}$ adsorben $\mathrm{Si}$ DPZIDA dengan $25 \mathrm{~mL}$ larutan multi logam dengan konsentrasi kation logam utama $5 \times 10^{-3} \mathrm{M}$ dan konsentrasi ko-logam bervariasi $0,5 \times 10^{-3}$, $1,0 \times 10^{-3}$, dan $1,5 \times 10^{-3} \mathrm{M}, \mathrm{pH} 2$, dengan lama pengadukan 3 jam.

\section{Adsorpsi binary ion logam $\mathrm{Cr}$ (III) dan $\mathrm{Pb}$ (II) pada Si-DPZIDA}

Berdasarkan kurva pada Gambar 1, teramati bahwa kehadiran ko-kation $\mathrm{Pb}$ (II) pada adsorpsi $\mathrm{Cr}(\mathrm{III})$ memberikan efek sinergistik yaitu menguatkan daya adsorpsi $\mathrm{Cr}$ (III) pada adsorben. Jumlah Cr(III) yang terserap pada sistem dengan kehadiran $\mathrm{Pb}$ (II) lebih besar dibandingkan dengan tanpa kehadiran $\mathrm{Pb}$ (II). Efek sinergistik tertinggi diberikan oleh kehadiran $\mathrm{Pb}$ (II) pada sistem dengan konsentrasi $0,5 \mathrm{mM}$, dengan daya serap $0,1041 \mathrm{mmol} / \mathrm{g}$, sedangkan pada sistem tanpa kehadiran $\mathrm{Pb}$ (II) daya serap terhadap $\mathrm{Cr}(\mathrm{III})$ adalah $0,0591 \mathrm{mmol} / \mathrm{g}$.

Kurva pada Gambar 2 menunjukkan bahwa terjadi peningkatan daya serap $\mathrm{Pb}$ (II) pada Si-DPZIDA dibandingkan dengan tanpa kehadiran ko-kation Cr(III). Efek sinergistik tertinggi terjadi pada kehadiran $\mathrm{Cr}$ (III) dengan konsentrasi 1,5 $\mathrm{mM}$, dengan daya serap 0,5808 $\mathrm{mmol} / \mathrm{g}$, sedangkan pada sistem tanpa kehadiran Cr(III) daya serap $\mathrm{Pb}$ (II) sebesar $0,5878 \mathrm{mmol} / \mathrm{g}$.

Berdasarkan kurva pada Gambar 3, teramati bahwa kehadiran ko-kation $\mathrm{Cu}$ (II) pada adsorpsi $\mathrm{Cr}$ (III) memberikan efek sinergistik yaitu menguatkan daya adsorpsi $\mathrm{Cr}$ (III) pada adsorben. Jumlah Cr(III) yang terserap pada sistem dengan kehadiran $\mathrm{Cu}$ (II) lebih besar dibandingkan dengan tanpa kehadiran $\mathrm{Cu}(\mathrm{II})$. Efek sinergistik tertinggi diberikan oleh kehadiran $\mathrm{Cu}(\mathrm{II})$ pada sistem dengan konsentrasi $0,5 \mathrm{mM}$, dengan daya serap $0,1010 \mathrm{mmol} / \mathrm{g}$, sedangkan pada sistem tanpa kehadiran $\mathrm{Cu}(\mathrm{II})$ daya serap terhadap $\mathrm{Cr}$ (III) adalah $0,0591 \mathrm{mmol} / \mathrm{g}$. 


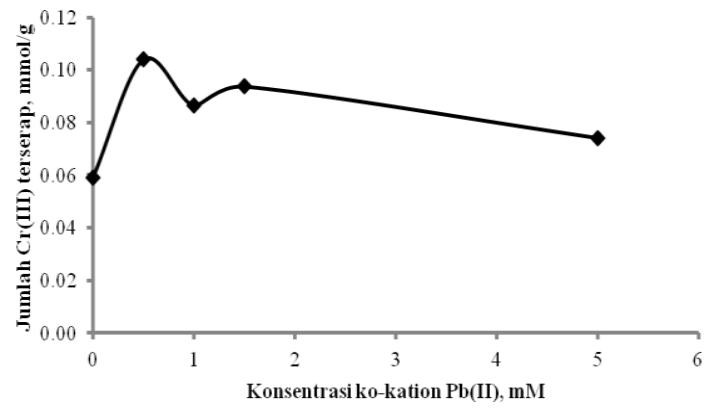

Gambar 1. Daya adsorpsi Si-DPZIDA terhadap ion $\mathrm{Cr}(\mathrm{III})$ dengan kehadiran ko-kation $\mathrm{Pb}$ (II) pada sistem binary $\mathrm{Cr}-\mathrm{Pb}$.

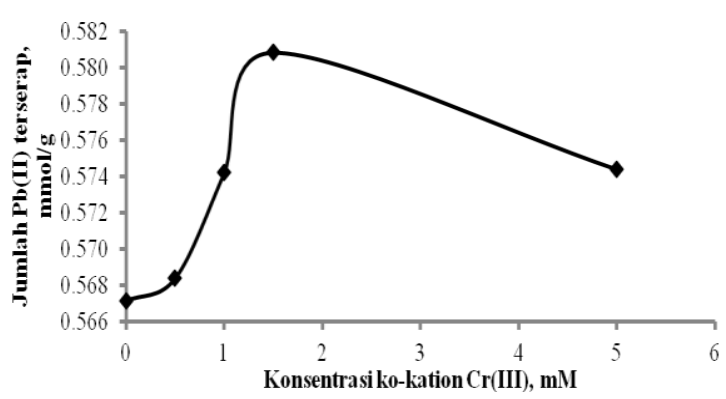

Gambar 2. Daya adsorpsi Si-DPZIDA terhadap ion $\mathrm{Pb}$ (II) dengan kehadiran ko-kation $\mathrm{Cr}(\mathrm{III})$ pada sistem binary $\mathrm{Pb}-\mathrm{Cr}$.

\section{Adsorpsi binary ion logam $\mathrm{Cr}$ (III) dan $\mathrm{Cu}$ (II) pada Si-DPZIDA}

Kurva pada Gambar 4 menunjukkan bahwa terjadi penurunan daya serap $\mathrm{Cu}$ (II) pada Si-DPZIDA dibandingkan dengan tanpa kehadiran ko-kation $\mathrm{Cr}(\mathrm{III})$. Efek antagonistik tertinggi

\section{Adsorpsi binary ion logam $\mathrm{Pb}$ (II) dan $\mathrm{Cu}(\mathrm{II})$ pada Si-DPZIDA}

Kurva pada Gambar 5 menunjukkan bahwa terjadi peningkatan daya serap $\mathrm{Pb}$ (II) pada Si-DPZIDA dibandingkan dengan tanpa kehadiran ko-kation $\mathrm{Cu}(\mathrm{II})$. Efek sinergistik tertinggi terjadi pada kehadiran $\mathrm{Cu}$ (II) dengan konsentrasi $1 \mathrm{mM}$, dengan daya serap $0,5867 \mathrm{mmol} / \mathrm{g}$, sedangkan pada sistem tanpa kehadiran $\mathrm{Cu}$ (II) daya serap $\mathrm{Pb}$ (II) sebesar 0,5672 $\mathrm{mmol} / \mathrm{g}$.

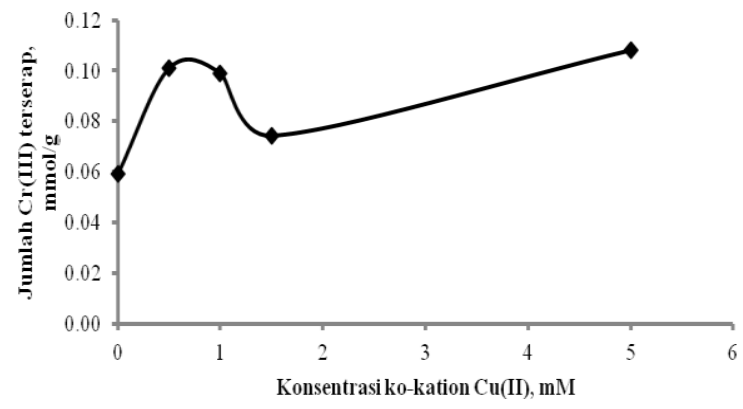

Gambar 3. Daya adsorpsi Si-DPZIDA terhadap ion $\mathrm{Cr}(\mathrm{III})$ dengan kehadiran ko-kation $\mathrm{Cu}$ (II) pada sistem binary $\mathrm{Cr}-\mathrm{Cu}$

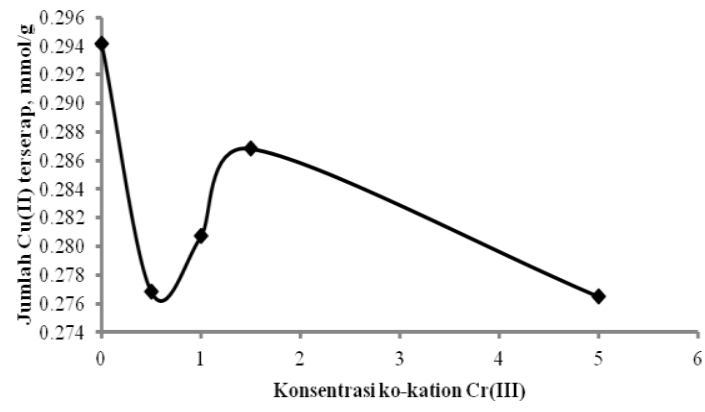

Gambar 4. Daya adsorpsi Si-DPZIDA terhadap ion $\mathrm{Cu}(\mathrm{II})$ dengan
kehadiran ko-kation $\mathrm{Cr}(\mathrm{III})$ pada sistem binary $\mathrm{Cu}-\mathrm{Cr}$

terjadi pada kehadiran $\mathrm{Cr}$ (III) dengan konsentrasi 0,5 $\mathrm{mM}$, dengan daya serap 0,2768 $\mathrm{mmol} / \mathrm{g}$, sedangkan pada sistem tanpa kehadiran Cr(III) daya serap $\mathrm{Cu}(\mathrm{II})$ sebesar $0,2941 \mathrm{mmol} / \mathrm{g}$.

Kurva pada Gambar 6 menunjukkan bahwa terjadi penurunan daya serap $\mathrm{Cu}$ (II) pada Si-DPZIDA dibandingkan dengan tanpa kehadiran ko-kation $\mathrm{Pb}$ (II). Efek antagonistik tertinggi terjadi pada kehadiran $\mathrm{Pb}$ (II) dengan konsentrasi $0,5 \mathrm{mM}$, dengan daya serap $0,2736 \mathrm{mmol} / \mathrm{g}$, sedangkan pada sistem tanpa kehadiran $\mathrm{Pb}$ (II) daya serap $\mathrm{Cu}$ (II) sebesar 0,2941 $\mathrm{mmol} / \mathrm{g}$. 

Oleh Silika Gel Terimobilisasi Difenilkarbazida

( I W. Sudiarta, P. Suarya, dan C. M. P. Widya)

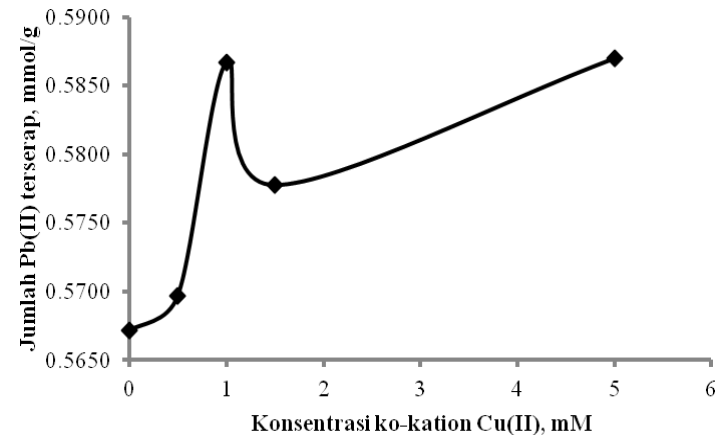

Gambar 5. Daya adsorpsi Si-DPZIDA terhadap ion $\mathrm{Pb}(\mathrm{II})$ dengan kehadiran ko-kation $\mathrm{Cu}(\mathrm{II})$ pada sistem binary $\mathrm{Pb}-\mathrm{Cu}$

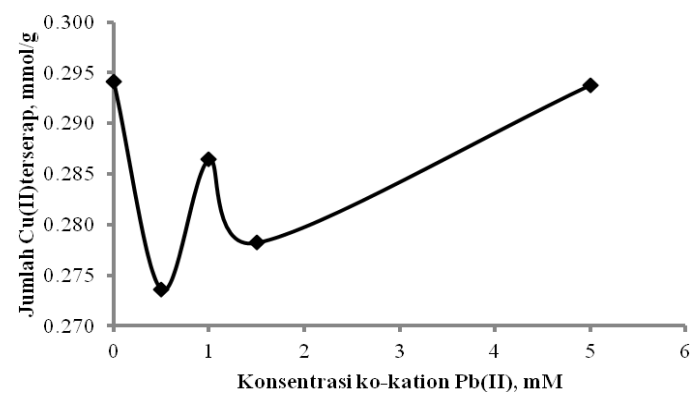

Gambar 6. Daya adsorpsi Si-DPZIDA terhadap ion $\mathrm{Cu}(\mathrm{II})$ dengan kehadiran ko-kation $\mathrm{Pb}(\mathrm{II})$ pada sistem binary $\mathrm{Cu}-\mathrm{Pb}$

Adsorpsi multi logam $\mathrm{Pb}, \mathrm{Cu}$, dan $\mathrm{Cr}$ dalam sistem binary menunjukkan daya serap yang beragam akibat kehadiran ko-kation logam lain. Kehadiran logam lain (ko-kation) pada adsorpsi logam $\mathrm{Pb}(\mathrm{II})$ dan $\mathrm{Cr}$ (III) menunjukkan efek sinergistik, sedangkan pada logam $\mathrm{Cu}$ (II) kehadiran logam lain memberikan efek antagonistik.

\section{KESIMPULAN}

Kehadiran ko-kation $\mathrm{Pb}(\mathrm{II})$ memberikan efek sinergistik pada adsorpsi $\mathrm{Cr}(\mathrm{III})$ yaitu meningkatkan jumlah $\mathrm{Cr}$ (III) yang terserap pada adsorben Si-DPZIDA dengan daya adsorpsi lebih besar dari $0.0591 \mathrm{mmol} / \mathrm{g}$. Efek sinergisitas terbesar terjadi pada ko-kation $\mathrm{Pb}$ (II) dengan konsentrasi $0,5 \mathrm{mM}$ dengan daya serap $\mathrm{Cr}$ (III) 0,1041 mmol/g. Ketika Cr(III) sebagai ko-kation, juga memberikan efek sinergistik pada adsorpsi
$\mathrm{Pb}$ (II) yaitu meningkatkan jumlah $\mathrm{Pb}$ (II) yang terserap pada Si-DPZIDA, dengan daya adsorpsi lebih besar dari $0,5672 \mathrm{mmol} / \mathrm{g}$. Efek sinergis terbesar terjadi pada kehadiran ko-kation $\mathrm{Cr}$ (III) dengan konsentrasi 1,5 mM, dengan daya serap $\mathrm{Pb}$ (II) $0,5808 \mathrm{mmol} / \mathrm{g}$. Dalam adsorpsi sistem binary $\mathrm{Cr}-\mathrm{Cu}$, ko-kation $\mathrm{Cu}$ (II) memberikan efek sinergistik yaitu meningkatkan jumlah $\mathrm{Cr}$ (III) yang terserap pada adsorben Si-DPZIDA dengan daya adsorpsi lebih besar dari $0.0591 \mathrm{mmol} / \mathrm{g}$. Efek sinergis terbesar terjadi pada kehadiran ko-kation $\mathrm{Cu}$ (II) pada sistem dengan konsentrasi $0,5 \mathrm{mM}$, dengan daya serap $\operatorname{Cr}(\mathrm{III}) \quad 0,1010 \mathrm{mmol} / \mathrm{g}$. Sedangkan ketika Cr(III) berfungsi sebagai kokation, memberikan efek antagonistik yaitu menurunkan jumlah $\mathrm{Cu}(\mathrm{II})$ yang terserap pada adsorben Si-DPZIDA dengan daya serap lebih rendah dari $0.2941 \mathrm{mmol} / \mathrm{g}$. Efek antagonis terbesar terjadi pada kehadiran ko-kation $\mathrm{Cr}$ (III) pada konsentrasi $0,5 \mathrm{mM}$, dengan daya serap $\mathrm{Cu}$ (II) $0,2768 \mathrm{mmol} / \mathrm{g}$. Dalam adsorpsi sistem binary $\mathrm{Pb}-\mathrm{Cu}$, ko-kation $\mathrm{Cu}$ (II) memberikan efek sinergistik yaitu meningkatkan jumlah $\mathrm{Pb}$ (II) yang terserap pada adsorben Si-DPZIDA dengan daya sorpsi lebih besar dari $0,5672 \mathrm{mmol} / \mathrm{g}$. Efek sinergis terbesar terjadi pada kehadiran ko-kation $\mathrm{Cu}$ (II) pada sistem dengan konsentrasi $1,0 \mathrm{mM}$, dengan daya serap $\mathrm{Pb}$ (II) $0,5867 \mathrm{mmol} / \mathrm{g}$. Sedangkan ketika $\mathrm{Pb}$ (II) berfungsi sebagai kokation, memberikan efek antagonistik yaitu menurunkan jumlah $\mathrm{Cu}(\mathrm{II})$ yang terserap pada adsorben Si-DPZIDA, dengan serapan lebih kecil dari dari $0.2941 \mathrm{mmol} / \mathrm{g}$. Efek antagonis terbesar terjadi pada kehadiran ko-kation $\mathrm{Pb}$ (II) pada konsentrasi $0,5 \mathrm{mM}$, dengan daya serap $\mathrm{Cu}(\mathrm{II})$ $0,2736 \mathrm{mmol} / \mathrm{g}$

\section{UCAPAN TERIMA KASIH}

Ucapan terima kasih penulis sampaikan kepada Universitas Udayana Kementerian Riset, Teknologi dan Pendidikan Tinggi atas dukungan finansial melalui Hibah Unggulan Program Studi tahun 2017.

\section{DAFTARPUSTAKA}

Chiban, M. \& Sinan, F., 2011, Removal of Cu (II) ions from aqueous solution by microparticles of dried Carpobrotus edulis plant 
in a column system, Water Qual Res J Can.,46 (3): 259-267.

Erdem, E., Karapinar, N., \& Donat, R., 2004, The Removal of Heavy Metal Cations by Natural Zeolite, Journal of Colloidand Interface Surface Science, 280: 309-314.

Ghasemi, M., Soudani, A., Zahedi, G., Goodarzi, M., \& Javadian, H., 2014, Kineticand Equilibrium study of Ni(II) sorption from aqueous solution onto Peganum harmalaL., Int. J Environ Sci. Technol., 1: 18351844.

Hadi, P., Barford, J., \& Mckay, G., 2014, Selective toxic metal uptake using an e waste based novel sorbent-single, binary and ternary systems, J Environ Chem Eng 2: 332-339.

Jain, M., Garg, V.K., \& Kadiverlu, K., 2010, Adsorption of heksavalent chromium from aqueous medium onto carbonaceous adsorbent prepared from waste biomass, Journal of Environmental Management, 91: 949-957.

Jain, M., Garg, V.K., \& Kadiverlu, K., 2013, Cadmium(II) sorption and desorption in a fixed bed columm usingg sunflower waste carbon calcium-alginate beads, Bioresourse Technoogyl, 129: 242-248.

Kocasoy, G. \& Sahin, V., 2007, Heavy Metal Removal from Industrial Wastewater by Clinoptilolite. Journal Environmental Science and Health Part A, 42, 2139-2146. http://www.ncbi.nlm.nih.gov/pubmed/180 74286.

Machida, M., Mochimaru, T., \& Tatsumoto, H., 2006, Lead(II) adsorption onto the graphene layer of carbonaceous materials in aqueous solution, Carbon, 44: 26812688.

Mahajan, G., \& Sud, D., 2013, Application of lingo-cellulotic waste material for heavy metal ions removal from aqueous solution, Journal of Enviromental Chemical Engenering.,1: 1020-1027.

Mahmoud, M., \& Al-Saadi, M.S.M., 2007, Silica gel-physically adsorbed diphenylcarbazone as a selective solid phase extractor and pre-concentrator for chromium(III) and iron(III), Journal of Saudi Chemical Society., 11(2): 331-340.
Mohan, D. \& Singh, K.P., 2002, Single and multicomponent adsorption cadmium and Zinc using activated carbon derived from bagasse-an agricultural waste, Water Resoursce, 36: 2304-2318.

Myroslav, S., Boguslaw. B., Artur, P.T., \& Jacek, N., 2006, Study of the selection mechanism of heavy metals $(\mathrm{Pb} 2+, \mathrm{Cu} 2+$, $\mathrm{Ni} 2+$, and $\mathrm{Cd} 2+)$ adsorption on clinoptilolite, Journal of Colloid and Interface Science, 304 (1): 21-28.

Oscik, J., 1982, Adsorption, John Willey \& Sons, Inc. New York.

Reddy, P. M. K., Krishanmurthy, K., Mahammaddunissa, S.K., Dayamani, K., \& Subrahmanyam, C., 2015, Preparation of activated carbon from bio-waste: Effect of surface functional groups on methylene blue adsorption, International Journal of Environmental Scence Technology.,12: 1363-1372.

Saeed, A., Iqbal M., \& Akhtar M.W., 2005, Removal and recoveryof lead(II) from single and multimetal $(\mathrm{Cd}, \mathrm{Cu}, \mathrm{Ni}, \mathrm{Zn})$ solution by crop milling waste (black gram husk), Journal of Hazard Matererial B117, 65-73.

Srivastava V.C., Mall I.D., \& Mishra I.M., 2006, Modelling individual and competitive adsorption cadmium(II) and Zinc(II) metal ions from aqueous solution onto bagase fly ash, Separation Science Technology., 50: 113-117.

Srivastava, P., Singh, B. \& Angove, M., 2005, Competitiveadsorption behavior of heavy metal on kaolinite, Journal of Colloid and Interface Science, 290: 28-38.

Tin, Y.P., \& Teo, W.K., 1994, Uptake of Cadmium and Zinc by Yeast : Effects of Co-metal Ion and Physical/Chemical Treatments, Bioresourse Technology., 50: 113-117.

Vinh N.V., ZafarM., Behera S.K., \& Park H.S., 2015, Arsenic(III) removal from aqueous solution by raw and zing-loaded pine cone biochar: equilibrium, kinetics, and thermodynamics studies, International Journal of Environmental Science Technology, 12: 1283-1294. 